\title{
Thalassobacillus hwangdonensis sp. nov., isolated from a tidal flat sediment
}

Correspondence

Jung-Hoon Yoon

jhyoon@kribb.re.kr

\author{
Soo-Young Lee, Tae-Kwang Oh and Jung-Hoon Yoon
}

Korea Research Institute of Bioscience and Biotechnology (KRIBB), PO Box 115, Yusong, Taejon, Republic of Korea

\begin{abstract}
A Gram-staining-positive, endospore-forming, motile, rod-shaped bacterium, strain $A D-1^{\top}$, was isolated from a tidal flat sediment of the coast of Hwangdo on the Yellow Sea, Korea. Strain AD- $1^{\top}$ grew optimally at $\mathrm{pH} 7.0-7.5$ and $40{ }^{\circ} \mathrm{C}$ and in the presence of $5-10 \%(\mathrm{w} / \mathrm{v}) \mathrm{NaCl}$.

Phylogenetic analysis based on $16 \mathrm{~S}$ rRNA gene sequences showed that strain $A D-1^{\top}$ was most closely related to Thalassobacillus devorans $\mathrm{G}-19.1^{\top}$ (98.0\% sequence similarity) and Thalassobacillus cyri $\mathrm{HS}_{286}^{\top}$ (97.8\%). The cell-wall peptidoglycan was based on mesodiaminopimelic acid and MK-7 was the predominant menaquinone. The major polar lipids were diphosphatidylglycerol, phosphatidylglycerol and two unidentified lipids. The major fatty acids ( $>10 \%$ of total fatty acids) were iso- $C_{15: 0}$, iso- $C_{17: 0}$ and anteiso- $C_{15: 0}$. The DNA G $+C$ content of strain $A D-1^{\top}$ was 45.2 mol\%. It appears reasonable to classify strain $A D-1^{\top}$ as a member of the genus Thalassobacillus. There were differences in fatty acid profiles and phenotypic and genetic characteristics between strain $A D-1^{\top}$ and the type strains of the two Thalassobacillus species. On the basis of the data presented, strain $A D-1^{\top}$ represents a novel species within the genus Thalassobacillus, for which the name Thalassobacillus hwangdonensis sp. nov. is proposed. The type strain is $A D-1^{\top}\left(=\operatorname{KCTC} 13254^{\top}=\operatorname{CCUG~} 56607^{\top}\right)$.
\end{abstract}

The genus Thalassobacillus was first described by García et al. (2005) with the description of a single species, Thalassobacillus devorans. Subsequently, a second species of the genus has been described, Thalassobacillus cyri (Sanchez-Porro et al., 2009). Members of the genus Thalassobacillus have been isolated from saline soil and hypersaline lake water (García et al., 2005; Sanchez-Porro et al., 2009). T. devorans was isolated from a phenol enrichment of saline soil samples and was found to degrade phenol (García et al., 2005). The genus Thalassobacillus is characterized chemotaxonomically by having cell-wall peptidoglycan based on meso-diaminopimelic acid, MK-7 as the predominant menaquinone, anteiso- $\mathrm{C}_{15: 0}$ as the predominant fatty acid and a DNA G + C content of 42.4$43.0 \mathrm{~mol} \%$ (García et al., 2005; Sanchez-Porro et al., 2009). Many novel bacterial strains have been isolated recently from the coast of Hwangdo (Hwang island) on the Yellow Sea, Korea (Jung et al., 2010). One of these isolates, AD- $1^{\mathrm{T}}$, which was phylogenetically most closely related to the genus Thalassobacillus, is described in this study.

Tidal flat sediments were collected from the coast of Hwangdo and used as the source for the isolation of bacterial strains. The sediment samples were suspended in a $0.85 \% \mathrm{NaCl}$ solution. The suspensions were serially diluted, spread on modified S-G medium $\left(1^{-1}\right.$ distilled

The GenBank/EMBL/DDBJ accession number for the 16S rRNA gene sequence of strain $A D-1^{\top}$ is EU817571. water: $100 \mathrm{~g} \mathrm{NaCl}, 20 \mathrm{~g} \mathrm{MgSO}_{4} \cdot 7 \mathrm{H}_{2} \mathrm{O}, 2 \mathrm{~g} \mathrm{KCl}, 3 \mathrm{~g}$ trisodium citrate, $10 \mathrm{~g}$ yeast extract, $7.5 \mathrm{~g}$ Casamino acid, 15 g agar; pH 7.2; Sehgal \& Gibbons, 1960) and incubated at $25{ }^{\circ} \mathrm{C}$. The type strains of the two Thalassobacillus species were used as reference strains for the analyses of fatty acids, polar lipids and phenotypic properties and the determination of DNA-DNA relatedness. T. devorans DSM $16966^{\mathrm{T}}$ was purchased from the DSMZ and T. cyri HS286 ${ }^{\mathrm{T}}$ was a kind gift from Professor Antonio Ventosa (University of Seville, Spain). Strain AD- $1^{\mathrm{T}}$ was routinely cultivated at $40{ }^{\circ} \mathrm{C}$ on MSG agar (modified S-G medium containing $75 \mathrm{~g} \mathrm{NaCl}$ content $\mathrm{l}^{-1}$ ) for the determination of morphological, physiological and biochemical characteristics. The two reference strains were routinely cultivated at $37{ }^{\circ} \mathrm{C}$ on MSG agar to determine phenotypic characteristics and to obtain cell mass for polar lipid analysis and DNA-DNA hybridization experiments.

Cell morphology was examined by light microscopy (Nikon E600) and transmission electron microscopy (Philips CM20). Flagellation was determined with transmission electron microscopy using cells from exponentially growing cultures that were negatively stained with $1 \%(\mathrm{w} / \mathrm{v})$ phosphotungstic acid and air-dried. The Gram reaction was performed by using the bioMérieux Gram stain kit according to the manufacturer's instructions. Endospores were investigated by using Schaeffer-Fulton (Murray et al., 1994) and malachite green (Smibert \& Krieg, 1994) staining methods. Growth under anaerobic conditions was determined by 
incubation in a Forma anaerobic chamber on MSG agar and on MSG agar supplemented with $0.1 \%$ (w/v) potassium nitrate, both of which had been prepared under a nitrogen atmosphere. Growth at 4, 10, 15, 20, 25, 28, 30, 35, 37 and $40-50{ }^{\circ} \mathrm{C}$ (at intervals of $1{ }^{\circ} \mathrm{C}$ ) was determined on MSG agar. Growth with $0-25 \%, w / v, ~ N a C l$ (in increments of $1.0 \%$ ) was investigated by using liquid media prepared according to the formula of MSG agar except that $\mathrm{NaCl}$ and agar were excluded. Growth in the absence of $\mathrm{NaCl}$ was also investigated using trypticase soy broth prepared according to the formula of the Difco medium except that $0.45 \%(\mathrm{w} / \mathrm{v})$ $\mathrm{MgCl}_{2} \cdot 6 \mathrm{H}_{2} \mathrm{O}$ was included and $\mathrm{NaCl}$ was excluded. The $\mathrm{pH}$ range for growth was determined in MSG broth adjusted to $\mathrm{pH} 4.5-9.5$ (at intervals of $0.5 \mathrm{pH}$ units) by using sodium acetate/acetic acid and $\mathrm{Na}_{2} \mathrm{CO}_{3}$ buffers. Catalase and oxidase activities were determined as described by Cowan \& Steel (1965). Nitrate reduction, hydrolysis of aesculin, gelatin, urea and Tweens 20, 40, 60 and 80, indole production and methyl red and Voges-Proskauer reactions were tested as described by Lányí (1987) using artificial seawater (Bruns et al., 2001) for media preparation. Hydrolysis of casein, hypoxanthine, starch and xanthine was tested on MSG agar with the substrate concentrates described by Cowan \& Steel (1965). DNase activity was examined by using DNase test agar with methyl green (Difco) and supplementation with $10 \%(\mathrm{w} / \mathrm{v}) \mathrm{NaCl}$. Degradation of phenol was tested as described by García et al. (2005); T. devorans DSM $16966^{\mathrm{T}}$ was used as a positive control. $\mathrm{H}_{2} \mathrm{~S}$ production was tested as described by Bruns et al. (2001). Utilization of various substrates for growth was tested as described by Choi et al. (2006) with the modification that Noble agar (Difco) was used instead of Bacto agar. Carbon sources were sterilized by filtration and added to a final concentration of $0.2 \%(\mathrm{w} / \mathrm{v})$. Acid production from carbohydrates was investigated according to the method of Leifson (1963). Enzyme activities were determined by using the API ZYM and API 20E systems (bioMérieux). Susceptibility to antibiotics was investigated on MSG agar by using antibiotic discs with the following amounts ( $\mu \mathrm{g}$ per disc unless otherwise indicated): ampicillin (10), carbenicillin (100), cephalothin (30), chloramphenicol (100), gentamicin (30), kanamycin (30), lincomycin (15), neomycin (30), novobiocin (5), oleandomycin (15), penicillin $\mathrm{G}(20 \mathrm{U})$, polymyxin B (100 U), streptomycin (50) and tetracycline (30).

To collect cell biomass for DNA extraction and analysis of the cell-wall peptidoglycan, isoprenoid quinones and polar lipids, strain $\mathrm{AD}-1^{\mathrm{T}}$ was cultivated in MSG broth at $40{ }^{\circ} \mathrm{C}$ for 3 days. Chromosomal DNA was isolated and purified according to the method described by Yoon et al. (1996), with the exception that RNase T1 was used in combination with RNase A to minimize contamination by RNA. The $16 \mathrm{~S}$ rRNA gene was amplified by PCR using universal primers 5'-GAGTTTGATCCTGGCTCAG-3' and 5'-AGAAAGGAGGTGATCCAGCC- $3^{\prime}$, as described previously (Yoon et al., 1998). Sequencing of the amplification products and phylogenetic analysis were performed as described by Yoon et al. (2003). The isomer type of the diamino acid in the cell-wall peptidoglycan was analysed using TLC according to the method described by Komagata \& Suzuki (1987). Isoprenoid quinones were analysed using reversed-phase HPLC and a YMC ODS-A $(250 \times 4.6 \mathrm{~mm})$ column, as described by Komagata \& Suzuki (1987). For cellular fatty acid analysis, strain $\mathrm{AD}-1^{\mathrm{T}}$ and the two reference strains were cultivated under two different culture conditions: on MSG agar at $37{ }^{\circ} \mathrm{C}$ for 3 days and on solid SW-7.5 medium (Ventosa et al., 1982) at $37^{\circ} \mathrm{C}$ for 5 days. Fatty acids were extracted and fatty acid methyl esters were prepared according to the standard protocol of the MIDI/Hewlett Packard Microbial Identification System (Sasser, 1990). Polar lipids were extracted according to the procedures described by Minnikin et al. (1984) and identified by twodimensional TLC followed by spraying with appropriate detection reagents (Minnikin et al., 1984; Komagata \& Suzuki, 1987). The DNA G +C content was determined by the method of Tamaoka \& Komagata (1984) with the modification that DNA was hydrolysed using nuclease P1 (Sigma) and the resultant nucleotides were analysed by reversed-phase HPLC. DNA-DNA hybridization was performed fluorometrically by the method of Ezaki et al. (1989) using photobiotin-labelled DNA probes and microdilution wells. Hybridization was performed with five replications for each sample. The highest and lowest values obtained for each sample were excluded and the means of the remaining three values are quoted as DNA-DNA relatedness values.

The morphological, cultural, physiological and biochemical characteristics of strain $\mathrm{AD}-1^{\mathrm{T}}$ are given in the species description and in Table 1. The almost-complete 16S rRNA gene sequence of strain $\mathrm{AD}-1^{\mathrm{T}}$ determined in this study comprised 1522 nucleotides, representing approximately $96 \%$ of the $16 \mathrm{~S}$ rRNA gene sequence of Escherichia coli. In the phylogenetic tree based on the neighbour-joining algorithm (Fig. 1), strain $\mathrm{AD}-1^{\mathrm{T}}$ joined the cluster comprising T. devorans G-19.1 ${ }^{\mathrm{T}}$ and T. cyri HS286 ${ }^{\mathrm{T}}$. The cluster was supported by a bootstrap resampling value of $99.6 \%$ and was also found in the trees constructed using the maximum-likelihood and maximum-parsimony algorithms. Strain $\mathrm{AD}-1^{\mathrm{T}}$ exhibited $16 \mathrm{~S}$ rRNA gene sequence similarities of 98.0 and $97.8 \%$ with $T$. devorans $\mathrm{G}-19.1^{\mathrm{T}}$ and T. cyri $\mathrm{HS}_{286^{\mathrm{T}}}$, respectively, and less than $96.6 \%$ with the other sequences included in the phylogenetic analysis.

Strain $\mathrm{AD}-1^{\mathrm{T}}$ contained meso-diaminopimelic acid as the diamino acid in the cell-wall peptidoglycan. The predominant menaquinone detected in strain $\mathrm{AD}-1^{\mathrm{T}}$ was $\mathrm{MK}-7$ (peak area ratio of approximately $95 \%$ ). The cell-wall peptidoglycan and predominant menaquinone type of strain $\mathrm{AD}-1^{\mathrm{T}}$ were the same as those of the two reference strains (García et al., 2005; Sanchez-Porro et al., 2009). Strain $\mathrm{AD}-1^{\mathrm{T}}$ contained large amounts of branched fatty acids: the major fatty acid was iso- $\mathrm{C}_{15: 0}(48.9 \%)$, and significant amounts ( $>10 \%$ of total fatty acids) of iso$\mathrm{C}_{17: 0}$ and anteiso- $\mathrm{C}_{15: 0}$ were detected (Table 2). The cellular fatty acid profiles determined in this study for $T$. devorans DSM $16966^{\mathrm{T}}$ and T. cyri $\mathrm{HS}^{286^{\mathrm{T}}}{ }^{\text {were essentially }}$ the same as those determined previously, although there 
Table 1. Differential characteristics of strain $A D-1^{\top}$ and the type strains of Thalassobacillus species

Strains: 1 , Thalassobacillus hwangdonensis sp. nov. $\mathrm{AD}-1^{\mathrm{T}} ; 2$, T. devorans DSM $16966^{\mathrm{T}}$ (unless indicated, data from García et al., 2005); 3, T. cyri ${\text { HS2 } 266^{\mathrm{T}}}$ (Sanchez-Porro et al., 2009). All strains were positive for nitrate reduction, utilization of $\mathrm{L}$-arabinose ${ }^{*}, \mathrm{D}$-fructose, $\mathrm{D}$-glucose $\dagger$, maltose, D-mannose, trehalose, L-malate ${ }^{\star}$ and pyruvate, acid production from $\mathrm{D}$ fructose, D-glucose, D-mannose, maltose and trehalose and activity of alkaline phosphatase, esterase (C4) and $\alpha$-glucosidase. All strains were negative for the Voges-Proskauer test, phenylalanine deaminase*, production of indole and $\mathrm{H}_{2} \mathrm{~S} \neq$, hydrolysis of urea, utilization of Dxylose, formate and L-glutamate, acid production from L-arabinose, myo-inositol, lactose, raffinose, L-rhamnose, D-ribose, D-sorbitol and Dxylose, and activity of lipase (C14), valine arylamidase, cystine arylamidase, trypsin, acid phosphatase, $\alpha$ - and $\beta$-galactosidase, $\beta$ glucuronidase, $\beta$-glucosidase, $N$-acetyl- $\beta$-glucosaminidase, $\alpha$-mannosidase and $\alpha$-fucosidase.

\begin{tabular}{|c|c|c|c|}
\hline Characteristic & 1 & 2 & 3 \\
\hline Anaerobic growth & + & - & - \\
\hline Optimum growth temperature $\left({ }^{\circ} \mathrm{C}\right)$ & 40 & 37 & 40 \\
\hline \multicolumn{4}{|l|}{ Growth with $\mathrm{NaCl}(\%)$} \\
\hline Range & $0-20$ & $0.5-20$ & $1-15$ \\
\hline Optimum & $5-10$ & $7.5-10$ & 8 \\
\hline Oxidase & + & - & + \\
\hline Methyl red test & + & - & + \\
\hline \multicolumn{4}{|l|}{ Hydrolysis of: } \\
\hline Aesculin & - & - & + \\
\hline Casein & + & - & + \\
\hline Gelatin & - & + & - \\
\hline Starch & - & - & + \\
\hline \multicolumn{4}{|l|}{ Utilization of: $§$} \\
\hline D-Galactose & - & $+\dagger$ & + \\
\hline Sucrose & - & + & + \\
\hline Citrate & - & + & + \\
\hline Benzoate & - & + & + \\
\hline \multicolumn{4}{|l|}{ Acid produced from: $\$$} \\
\hline D-Galactose & - & - & + \\
\hline D-Mannitol & - & + & - \\
\hline Melezitose & - & + & - \\
\hline Melibiose & - & - & + \\
\hline Sucrose & - & + & - \\
\hline \multicolumn{4}{|l|}{ Enzyme activity (API ZYM)§ } \\
\hline Esterase lipase (C8) & + & - & + \\
\hline Leucine arylamidase & + & - & - \\
\hline Naphthol-AS-BI-phosphohydrolase & - & + & - \\
\hline DNA G $+\mathrm{C}$ content $(\mathrm{mol} \%)$ & 45.2 & 42.4 & 43.0 \\
\hline
\end{tabular}

${ }^{*}$ Data from this study; opposite result was obtained for $T$. devorans DSM $16966^{\mathrm{T}}$ by García et al. (2005).

$\dagger$ Data from this study; opposite result was obtained for T. cyri HS286 ${ }^{\mathrm{T}}$ by Sanchez-Porro et al. (2009).

$¥$ Data for T. devorans DSM $16966^{\mathrm{T}}$ from this study.

$\S D$ ata for reference strains from this study.

were differences in the contents of some fatty acids (García et al., 2005; Sanchez-Porro et al., 2009). The fatty acid profiles of the three strains were similar although there were differences in the proportions of the major fatty acids. Intrageneric differences in fatty acid profiles have been reported for members of some genera (Yoon et al., 2001; Hanada et al., 2002; Hua et al., 2007; Nam et al., 2008). The major polar lipids detected in strain $\mathrm{AD}-1^{\mathrm{T}}$ were diphosphatidylglycerol, phosphatidylglycerol and two unidentified lipids. The major polar lipids detected in T. devorans DSM $16966^{\mathrm{T}}$ in this study were diphosphatidylglycerol, phosphatidylglycerol, an unidentified lipid and an unidentified phospholipid. The major polar lipids detected in $T$. cyri $\mathrm{HS}_{286^{\mathrm{T}}}$ by Sanchez-Porro et al. (2009) were diphosphatidylglycerol, phosphatidylglycerol, two unidentified phospholipids and an unidentified glycolipid. The DNA $\mathrm{G}+\mathrm{C}$ content of strain $\mathrm{AD}-\mathrm{1}^{\mathrm{T}}$ was $45.2 \mathrm{~mol} \%$, which was a little higher than those reported for $T$. devorans DSM $16966^{\mathrm{T}}$ and T. cyri HS286 ${ }^{\mathrm{T}}$ (42.4 and $43.0 \mathrm{~mol} \%$, respectively; Table 1). Taking these data into account, it appears appropriate to classify strain $\mathrm{AD}-1^{\mathrm{T}}$ as a member of the genus Thalassobacillus.

Strain $\mathrm{AD}-1^{\mathrm{T}}$ exhibited mean DNA-DNA relatedness of 5 and $9 \%$ to T. devorans DSM $16966^{\mathrm{T}}$ and T. cyri HS286 ${ }^{\mathrm{T}}$, respectively. Strain $A D-1^{T}$ was distinguishable from $T$. devorans DSM $16966^{\mathrm{T}}$ and T. cyri HS286 ${ }^{\mathrm{T}}$ by differences in several phenotypic properties, including absence of endospores, anaerobic growth, oxidase activity and hydrolysis, utilization and acid production from carbohydrates and enzyme activities (Table 1). Therefore, the genetic distinctiveness and differential phenotypic properties are sufficient to categorize strain $\mathrm{AD}-1^{\mathrm{T}}$ in a novel species within the genus Thalassobacillus (Wayne et al., 1987; Stackebrandt \& Goebel, 1994), for which the name Thalassobacillus hwangdonensis sp. nov. is proposed.

\section{Description of Thalassobacillus hwangdonensis sp. nov.}

Thalassobacillus hwangdonensis (hwang.do.nen'sis. N.L. masc. adj. hwangdonensis pertaining to Hwangdo, the Korean island from where the type strain was isolated).

Cells are Gram-stain-positive rods, $0.3-0.7 \times 1.2-3.5 \mu \mathrm{m}$. Motile by means of peritrichous flagella. Central or subterminal ellipsoidal endospores are observed in swollen sporangia. Colonies are circular, semi-translucent, slightly convex and moderate yellow, $1.2-2.0 \mathrm{~mm}$ in diameter after incubation on MSG agar for 3 days at $40{ }^{\circ} \mathrm{C}$. Growth occurs at $15-47{ }^{\circ} \mathrm{C}$ (optimum $40{ }^{\circ} \mathrm{C}$ ), at $\mathrm{pH}$ 6.0-9.0 (optimum $\mathrm{pH} 7.0-7.5$ ) and with $0-20 \%$ (w/v) $\mathrm{NaCl}$ (optimum 5-10\% $\mathrm{NaCl}) . \mathrm{Mg}^{2+}$ ions are required for growth. Anaerobic growth occurs on MSG agar and on MSG agar supplemented with nitrate. Oxidase-positive. Arginine dihydrolase, lysine decarboxylase, ornithine decarboxylase and phenylalanine deaminase activities are absent. Methyl red test is positive. Voges-Proskauer test is negative. $\mathrm{H}_{2} \mathrm{~S}$ and indole are not produced. Casein, DNA and Tweens 20, 40, 60 and 80 are hydrolysed, but aesculin, gelatin, hypoxanthine, xanthine, starch, L-tyrosine and urea are not. Phenol is not degraded. L-Arabinose, D-fructose, D-glucose, maltose, 


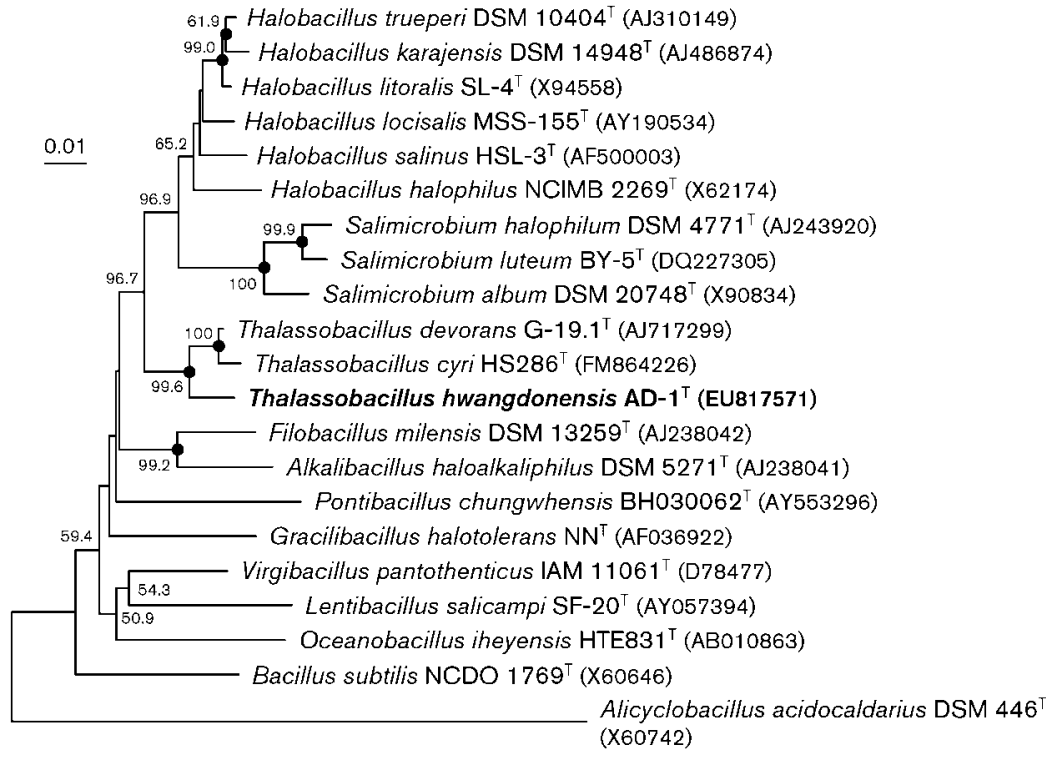

Fig. 1. Neighbour-joining tree based on $16 \mathrm{~S}$ rRNA gene sequences showing the phylogenetic positions of strain $A D-1^{\top}$ and related taxa. Bootstrap values $(>50 \%)$ based on 1000 replications are shown at branch nodes. Filled circles indicate that the corresponding nodes were also recovered in trees generated with the maximum-likelihood and maximum-parsimony algorithms. Alicyclobacillus acidocaldarius DSM $446^{\top}$ was used as an outgroup. Bar, 0.01 substitutions per nucleotide position. Note that the sequence corresponding to accession number $\mathrm{X} 62174$ is from strain NCIMB 2269 ${ }^{\top}$ (Farrow et al., 1992), not NCIMB 9251 as given in GenBank.
Table 2. Cellular fatty acid compositions of strain $A D-1^{\top}$ and the type strains of Thalassobacillus species

Strains: 1, T. hwangdonensis sp. nov. AD- $1^{\mathrm{T}} ; 2$, T. devorans DSM $16966^{\mathrm{T}}$; 3, T. cyri HS286 ${ }^{\mathrm{T}}$. All data were taken from this study after cultivation on MSG agar or solid SW-7.5 medium as described in the text. Fatty acids that represented $<1.0 \%$ in all strains were omitted. - , Not detected.

\begin{tabular}{|c|c|c|c|c|c|c|}
\hline \multirow[t]{2}{*}{ Fatty acid (\%) } & \multicolumn{2}{|c|}{1} & \multicolumn{2}{|r|}{2} & \multicolumn{2}{|c|}{3} \\
\hline & MSG & SW-7.5 & MSG & SW-7.5 & MSG & SW-7.5 \\
\hline \multicolumn{7}{|l|}{ Straight-chain } \\
\hline $\mathrm{C}_{16: 0}$ & 1.0 & 3.6 & 2.0 & 1.4 & 1.4 & 1.8 \\
\hline \multicolumn{7}{|l|}{ Unsaturated } \\
\hline $\begin{array}{r}\mathrm{C}_{16: 1} \omega 7 c \\
\text { alcohol }\end{array}$ & 0.4 & 0.3 & 0.4 & 0.2 & 0.8 & 1.4 \\
\hline \multicolumn{7}{|l|}{ Branched } \\
\hline iso- $\mathrm{C}_{14: 0}$ & - & 0.5 & 1.2 & 3.3 & 2.1 & 2.7 \\
\hline iso- $\mathrm{C}_{15: 0}$ & 48.9 & 43.0 & 9.6 & 8.1 & 7.4 & 11.8 \\
\hline anteiso- $\mathrm{C}_{15: 0}$ & 11.4 & 18.5 & 53.6 & 59.2 & 51.6 & 49.3 \\
\hline iso- $\mathrm{C}_{16: 0}$ & 1.0 & 5.0 & 9.0 & 10.5 & 11.4 & 13.1 \\
\hline iso- $\mathrm{C}_{17: 0}$ & 18.0 & 13.6 & 2.6 & 0.9 & 2.3 & 2.6 \\
\hline anteiso- $\mathrm{C}_{17: 0}$ & 7.9 & 13.1 & 15.2 & 11.0 & 19.6 & 14.5 \\
\hline anteiso- $\mathrm{C}_{17: 1}$ & - & - & 2.9 & 2.0 & 1.9 & 1.6 \\
\hline iso- $\mathrm{C}_{17: 1} \omega 10 c$ & 7.4 & 0.4 & - & - & - & - \\
\hline \multicolumn{7}{|l|}{ Summed features* } \\
\hline 2 & - & - & 0.7 & 0.9 & 0.4 & 1.1 \\
\hline 3 & - & 0.1 & 1.4 & 1.0 & 0.5 & - \\
\hline 4 & 3.6 & 0.4 & - & - & - & - \\
\hline
\end{tabular}

*Summed features represent groups of two or three fatty acids that cannot be separated by the Microbial Identification System. Summed feature 2 consisted of iso- $\mathrm{C}_{16: 1}$ and/or $\mathrm{C}_{14: 0} 3-\mathrm{OH}$. Summed feature 3 consisted of $\mathrm{C}_{16: 1} \omega 7 c$ and/or iso- $\mathrm{C}_{15: 0} 2-\mathrm{OH}$. Summed feature 4 consisted of iso- $\mathrm{C}_{17: 1} \mathrm{I}$ and/or anteiso- $\mathrm{C}_{17: 1} \mathrm{~B}$. carbon and energy sources, but cellobiose, D-galactose, sucrose, D-xylose, acetate, benzoate, citrate, formate, Lglutamate, succinate and salicin are not. Acid is produced from D-fructose, D-glucose, D-mannose, maltose, trehalose and cellobiose (weakly), but not from L-arabinose, Dgalactose, myo-inositol, lactose, D-mannitol, melezitose, melibiose, raffinose, L-rhamnose, D-ribose, D-sorbitol, sucrose or D-xylose. Alkaline phosphatase, esterase (C4), esterase lipase (C8), leucine arylamidase and $\alpha$-glucosidase activities are present and weak $\alpha$-chymotrypsin activity is present, but lipase (C14), valine arylamidase, cystine arylamidase, trypsin, acid phosphatase, naphthol-AS-BIphosphohydrolase, $\alpha$ - and $\beta$-galactosidase, $\beta$-glucuronidase, $\beta$-glucosidase, $N$-acetyl- $\beta$-glucosaminidase, $\alpha$-mannosidase and $\alpha$-fucosidase activities are absent. Susceptible to ampicillin, carbenicillin, cephalothin, chloramphenicol, lincomycin, novobiocin, oleandomycin and penicillin $\mathrm{G}$, but not to gentamicin, kanamycin, neomycin, polymyxin B, streptomycin or tetracycline. The cell-wall peptidoglycan contains meso-diaminopimelic acid. The predominant menaquinone is MK-7. The major polar lipids are diphosphatidylglycerol, phosphatidylglycerol and two unidentified lipids. The major fatty acids ( $>10 \%$ of total fatty acids) are iso- $\mathrm{C}_{15: 0}$, iso- $\mathrm{C}_{17: 0}$ and anteiso- $\mathrm{C}_{15: 0}$. The DNA $\mathrm{G}+\mathrm{C}$ content of the type strain is $45.2 \mathrm{~mol} \%$ (HPLC).

The type strain, AD- $1^{\mathrm{T}}$ (=KCTC $13254^{\mathrm{T}}=\mathrm{CCUG} 56607^{\mathrm{T}}$ ), was isolated from a tidal flat sediment of the coast of Hwangdo on the Yellow Sea, Korea.

\section{Acknowledgements}

This work was supported by the Program for Collection, Management and Utilization of Biological Resources (grant no. M10867010003), the 21C Frontier Program of Microbial Genomics and Applications (grant no. MG05-0401-2-0) of the Ministry of Education, Science \& Technology (MEST) of the Republic of Korea and by a grant from the 
KRIBB Research Initiative Program. We are grateful to Professor Antonio Ventosa for providing Thalassobacillus cyri $\mathrm{HS}_{286^{\mathrm{T}}}$.

\section{References}

Bruns, A., Rohde, M. \& Berthe-Corti, L. (2001). Muricauda ruestringensis gen. nov., sp. nov., a facultatively anaerobic, appendaged bacterium from German North Sea intertidal sediment. Int $J$ Syst Evol Microbiol 51, 1997-2006.

Choi, D. H., Yi, H., Chun, J. \& Cho, B. C. (2006). Jannaschia seosinensis sp. nov., isolated from hypersaline water of a solar saltern in Korea. Int J Syst Evol Microbiol 56, 45-49.

Cowan, S. T. \& Steel, K. J. (1965). Manual for the Identification of Medical Bacteria. London: Cambridge University Press.

Ezaki, T., Hashimoto, Y. \& Yabuuchi, E. (1989). Fluorometric deoxyribonucleic acid-deoxyribonucleic acid hybridization in microdilution wells as an alternative to membrane filter hybridization in which radioisotopes are used to determine genetic relatedness among bacterial strains. Int J Syst Bacteriol 39, 224-229.

Farrow, J. A. E., Ash, C., Wallbanks, S. \& Collins, M. D. (1992). Phylogenetic analysis of the genera Planococcus, Marinococcus and Sporosarcina and their relationships to members of the genus Bacillus. FEMS Microbiol Lett 93, 167-172.

Garcia, M. T., Gallego, V., Ventosa, A. \& Mellado, E. (2005). Thalassobacillus devorans gen. nov., sp. nov., a moderately halophilic, phenol-degrading, Gram-positive bacterium. Int J Syst Evol Microbiol 55, 1789-1795.

Hanada, S., Liu, W. T., Shintani, T., Kamagata, Y. \& Nakamura, K. (2002). Tetrasphaera elongata sp. nov., a polyphosphate-accumulating bacterium isolated from activated sludge. Int J Syst Evol Microbiol 52, 883-887.

Hua, N.-P., Kanekiyo, A., Fujikura, K., Yasuda, H. \& Naganuma, T. (2007). Halobacillus profundi sp. nov. and Halobacillus kuroshimensis sp. nov., moderately halophilic bacteria isolated from a deep-sea methane cold seep. Int J Syst Evol Microbiol 57, 1243-1249.

Jung, Y.-T., Kim, B.-H., Oh, T.-K. \& Yoon, J.-H. (2010). Pseudoruegeria lutimaris sp. nov., isolated from a tidal flat sediment, and emended description of the genus Pseudoruegeria. Int J Syst Evol Microbiol 60, 1177-1181.

Komagata, K. \& Suzuki, K. (1987). Lipid and cell-wall analysis in bacterial systematics. Methods Microbiol 19, 161-207.

Lányí, B. (1987). Classical and rapid identification methods for medically important bacteria. Methods Microbiol 19, 1-67.

Leifson, E. (1963). Determination of carbohydrate metabolism of marine bacteria. J Bacteriol 85, 1183-1184.

Minnikin, D. E., O'Donnell, A. G., Goodfellow, M., Alderson, G., Athalye, M., Schaal, A. \& Parlett, J. H. (1984). An integrated procedure for the extraction of bacterial isoprenoid quinones and polar lipids. J Microbiol Methods 2, 233-241.
Murray, R. G. E., Doetsch, R. N. \& Robinow, C. F. (1994). Determinative and cytological light microscopy. In Methods for General and Molecular Bacteriology, pp. 21-41. Edited by P. Gerhardt, R. G. E. Murray, W. A. Wood \& N. R. Krieg. Washington, DC: American Society for Microbiology.

Nam, J.-H., Bae, W. \& Lee, D.-H. (2008). Oceanobacillus caeni sp. nov., isolated from a Bacillus-dominated wastewater treatment system in Korea. Int J Syst Evol Microbiol 58, 1109-1113.

Sanchez-Porro, C., Amoozegar, M. A., Rohban, R., Hajighasemi, M. \& Ventosa, A. (2009). Thalassobacillus cyri sp. nov., a moderately halophilic Gram-positive bacterium from a hypersaline lake. Int J Syst Evol Microbiol 59, 2565-2570.

Sasser, M. (1990). Identification of bacteria by gas chromatography of cellular fatty acids, MIDI Technical Note 101. Newark, DE: MIDI Inc.

Sehgal, S. N. \& Gibbons, N. E. (1960). Effect of some metal ions on the growth of Halobacterium cutirubrum. Can J Microbiol 6, 165-169.

Smibert, R. M. \& Krieg, N. R. (1994). Phenotypic characterization. In Methods for General and Molecular Bacteriology, pp. 607-654. Edited by P. Gerhardt, R. G. E. Murray, W. A. Wood \& N. R. Krieg. Washington, DC: American Society for Microbiology.

Stackebrandt, E. \& Goebel, B. M. (1994). Taxonomic note: a place for DNA-DNA reassociation and $16 \mathrm{~S}$ rRNA sequence analysis in the present species definition in bacteriology. Int J Syst Bacteriol 44, 846849.

Tamaoka, J. \& Komagata, K. (1984). Determination of DNA base composition by reversed-phase high-performance liquid chromatography. FEMS Microbiol Lett 25, 125-128.

Ventosa, A., Quesada, E., Rodriguez-Valera, F., Ruiz-Berraquero, F. \& Ramos-Cormenzana, A. (1982). Numerical taxonomy of moderately halophilic Gram-negative rods. J Gen Microbiol 128, 1959-1968.

Wayne, L. G., Brenner, D. J., Colwell, R. R., Grimont, P. A. D., Kandler, O., Krichevsky, M. I., Moore, L. H., Moore, W. E. C., Murray, R. G. E. \& other authors (1987). International Committee on Systematic Bacteriology. Report of the ad hoc committee on reconciliation of approaches to bacterial systematics. Int J Syst Bacteriol 37, 463-464.

Yoon, J.-H., Kim, H., Kim, S.-B., Kim, H.-J., Kim, W. Y., Lee, S. T., Goodfellow, M. \& Park, Y.-H. (1996). Identification of Saccharomonospora strains by the use of genomic DNA fragments and rRNA gene probes. Int J Syst Bacteriol 46, 502-505.

Yoon, J.-H., Lee, S. T. \& Park, Y.-H. (1998). Inter- and intraspecific phylogenetic analysis of the genus Nocardioides and related taxa based on 16S rDNA sequences. Int J Syst Bacteriol 48, 187-194.

Yoon, J.-H., Kang, S.-S., Lee, K.-C., Kho, Y. H., Kang, K. H. \& Park, Y.-H. (2001). Planomicrobium koreense gen. nov., sp. nov., a bacterium isolated from the Korean traditional fermented seafood jeotgal, and transfer of Planococcus okeanokoites (Nakagawa et al. 1996) and Planococcus momeekinii (Junge et al. 1998) to the genus Planomicrobium. Int J Syst Evol Microbiol 51, 1511-1520.

Yoon, J.-H., Kim, I.-G., Shin, D.-Y., Kang, K. H. \& Park, Y.-H. (2003). Microbulbifer salipaludis sp. nov., a moderate halophile isolated from a Korean salt marsh. Int J Syst Evol Microbiol 53, 53-57. 